\title{
Domestic Climate Change Governance in East Asia: A Comparative Analysis of Japan, China and South
}

\section{Korea}

\author{
Josef Falko Loher
}

\begin{abstract}
This article deals with domestic climate change governance in Japan, China and South Korea between 1997 and 2010. It examines whether the modes of governance of these three states show congruencies. In order to test this, the thesis uses a model of analysis by Treib, Bähr and Falkner, which examines seven categories within the three dimensions of polity, politics and policy. In each category, corresponding modes of governance are located on a spectrum between state intervention and societal autonomy. As the results of the analysis show, the hypothesis of congruent modes of governance in all three East Asian states cannot be confirmed. However, Japan and China show strong similarities in six out of seven categories. Modes in both states can be located on the traditional side of the spectrum tending towards state intervention. South Korea's modes of governance differ as they are hybrid in most of the categories. However, since the enforcement of the Korean Low Carbon, Green Growth Strategy in April 2010, Korea seems to be moving towards Japan's and China's so-called traditional modes of governance.
\end{abstract}

Keywords: Governance, climate change governance, climate change policy, Japan, China, South Korea, East Asia

D1ae Loher, Josef Falko. "Domestic Climate Change Governance in East Asia: A Comparative Analysis of Japan, China and South Korea." In Vienna Journal of East Asian Studies, Volume 3, eds. Rudiger Frank, Ingrid Getreuer-Kargl, Lukas Pokorny and Agnes Schick-Chen. Vienna: Praesens Verlag, 2012, pp. 73-107. https://doi.org/10.2478/vjeas-2012-0003 


\section{Introduction}

Climate change poses one of the greatest threats to human security on a global scale. There is strong scientific consensus that - in the event of continued global warming - the world will be exposed to multiple negative effects in the long run. The East Asian region ${ }^{1}$ is especially vulnerable to climate change. The United Nations Framework Convention on Climate Change (UNFCCC) has pointed out that probable threats through global warming in the region are increasing water stress due to diminishing freshwater abilities, the growing number and severity of floods related to glacial melt, falling amounts of crop yields, land degradation and desertification, heat stress and similar health problems, coastal inundation and increases in the intensity of tropical cyclones as well as the widening extents of forest fires (UNFCCC 2007).

Moreover, the region is a major source of greenhouse gas emissions. China recently admitted it was the number one emitter of greenhouse gases in the world (Reuters, 23 November 2010). Japan and Korea also rank among the top ten greenhouse gas-emitting countries globally (Asian Development Bank 2009). Primary factors for the dramatic increase in emissions throughout the region are rapid economic growth, an increase in the number of vehicles and ongoing trends in urbanisation, as well as growing energy demand (Asian Development Bank 2009).

As figures such as those for GDP and population and other factors negative for climate change are expected to grow, there is a consensus on the urgency of efficient mitigation and adaptation policies on all levels of political action. As the UNFCCC climate conferences in Copenhagen and Cancún failed to produce any results in the sense of mandatory targets for member countries and as regional co-operation is comparatively low, the media response is rather negative about the results of effective mitigation in East Asia. However, all three East Asian nation-states subject to this analysis are members of the UNFCCC and have committed themselves to the implementation of climate change policies on a domestic level. In periodical national reports they list implemented and planned climate change measures in six different sectors. ${ }^{2}$ Japan, China and South Korea implement climate change policies under different circumstances and within different political and societal settings. ${ }^{3}$

1 In this article, the East Asian region embraces the Republic of Korea (ROK; from hereon South Korea), the state of Japan (Japan) and the People's Republic of China (China). As Taiwan is not a member state of the United Nations and therefore does not send national reports to the UNFCCC, it is not included in this analysis. These are the bases for the analysis.

2 These are transport, energy, industry, waste management, agriculture, and LULUCF (land use, land-use change and forestry) (UNFCCC 2003: 36-48).

3 As an example, Japan committed to a 6 percent reduction target within the Kyōto Protocol, whereas South Korea and China did not (Government of Japan 2010: 36; UNFCCC 2003). 
However, the efficiency of climate change policies does not necessarily rely on targets, but depends on various factors: will, capabilities, financial resources andamong others - reliable and efficient steering and co-ordination systems (hereafter called climate change governance). The modes of such steering and co-ordination can be observed and analysed with the use of methodological frameworks. This article will conduct such an analysis, basing itself on Shin Sangbum's assumption that there is a common model of domestic environmental governance in East Asia in terms of key actors, the role of civil society and key characteristics (Shin 2009: 23). Following on from this, it is of great interest to find out whether there is a similar model in domestic climate change governance in the region.

In order to do this, I aim to analyse and compare modes of governance in Japanese, Chinese and Korean domestic climate change policy. These modes can be examined in three political dimensions: the normative and institutional frame (polity), the processual level (politics), and the outputs and steering instruments (policy). To conduct such an analysis thoroughly, a governance analysis model by Oliver Treib, Holger Bähr and Gerda Falkner will be applied (Treib, Bähr and Falkner 2005). This model allows the localisation of modes of governance in seven categories along the three dimensions on a spectrum between state intervention and societal self-regulation. By determining the respective modes on these spectrums in each country, a methodologically grounded comparison of the climate change governance settings of all three countries can be made. The model seems most suited to a comprehensive analysis of climate change governance modes. It involves all three dimensions of politics, which makes it operational for all aspects of politics. Moreover, applying localisation on the respective spectrums allows comparison between the countries and analysis regarding the role of the state. ${ }^{4}$

The research question for this article is thus the following: Do Japan, China and South Korea share the same modes of domestic climate change governance? Can we speak of a common model of East Asian climate change governance as Shin does in terms of domestic environmental governance? The hypothesis informing my work refers to this research question: that there are congruent modes of domestic climate change governance in Japan, China and South Korea, and that therefore we can speak of a common model of East Asian climate change governance.

The time frame of the analysis will embrace the years 1997 to 2010. Although global activities in climate change politics had started earlier, the ratification of the Kyōto Protocol in December 1997 marks the beginning of modern global warming countermeasures. From this date on, East Asian nation states founded climate

4 Other analytical frameworks which aim at analysing governance modes, for instance, include Hufty (2009) and Walker (2005). For the purpose of this analysis, Treib, Bähr and Falkner's model seems most suitable in terms of operationability, comparability, and its focus on the domestic level of politics and on the role of the state. 
change institutions and implemented national programmes on a broad scale. The end point of this work is 2010, more exactly after the enactment of the Low Carbon, Green Growth Strategy ${ }^{5}$ in South Korea in April which-as the analysis will show-marks a shift in Korean climate change policy. To carry out the analysis, I use legislation of the three states as well as secondary sources.

So far, the literature in the field of East Asian climate change governance is scarce. Analyses have mostly been conducted on national and sub-national levels, seldom from a comparative perspective. Miranda Schreurs has conducted wide research on Japanese climate change governance (Schreurs 2002; 2008; 2010), and Qi Ye, Ma Li, Zhang Huanbo and Li Huimin as well as David Held, Eva-Maria Nag and Charles Rogers have dealt with Chinese climate change governance (Qi et al. 2008; Held, Nag and Rogers 2011). Oh Ilyoung is one of the few authors dealing with Korean climate change policies (Oh 2008). Schreurs conducted an analysis of East Asian climate change policies from a comparative, multi-level governance perspective with focus on the local level (Schreurs 2010).

This article will deal initially with the theoretical framing and methodological tools which are indispensable for answering the research question and verifying the hypothesis. Within this section I will introduce seven categories of analysis drawn from Treib, Bähr and Falkner's model. I will then briefly sketch the main characteristics of national climate change policies in East Asian nation states to show differing settings in each state. Following this, I will analyse each country's climate change polities, politics and policies within the seven categories and identify and localise the respective governing modes. In conclusion, I will compare the localisations in all seven categories and answer the research question.

\section{Theory and methods}

\section{The concept of governance}

Since the early 1990s, governance research has developed to become one of the key concepts in multiple scientific disciplines, such as sociology, economics or jurisprudence. Governance does not represent a consistent discipline, but is rather shaped by heterogeneity in origin, definition and application. Its roots can be found in institutional economic theory, international relations and the normative concept of Good Governance. The current discourse can be seen as a triad leading from planning to steering to governance (Schuppert 2008: 16). Whereas planning theory of the 1960s

5 The Korean name of this strategy is Chŏt'anso noksaeksŏngjang kibonbŏp 저탄소 녹색성장 기본법. I used the English translations of acts, plans, organisations, institutions and government departments as they appear in the sources. Wherever no English translations were named, I used my own translations. 
and 1970s still focused on a primarily hierarchical form of politics in which a central ministerial bureaucracy controlled power, steering theory already acknowledged further actors as part of the game. Governance theory emerged from the early 1990s on and moved away from this actor-centred approach. It analyses rule structures in which public and private, as well as hierarchical and network-based forms of steering coexist (Mayntz 2004).

Scientific discourse struggles to agree upon a common definition of governance. Treib, Bähr and Falkner narrow it down to 'steering and coordination of interdependent and (usually collective) actors based on institutionalised rule systems' (Treib, Bähr and Falkner 2005: 5). This definition follows the wide definitional foundation that includes all kinds of political steering regardless of whether composed of traditional or new types, of state or non-state actors. The narrow definition, however, takes governance to be a discipline that emphasises the dissolution of state monopolies and therefore only acknowledges non-hierarchical steering modes (Schuppert 2008: 25; Héritier 2002: 1). This study takes the wide definition as a basis for the following analysis.

There are some catchwords that appear frequently in the debates of governance. Firstly, 'networks' can be formed by different actors to achieve certain goals. They can be inter-governmental, inter-organisational, transnational or between state and society (Kjaer 2003: 2). Secondly, 'rules' or 'rules of the game' concern the institutional dimension of governance and name informal as well as formal rules, norms and patterns of behaviour: 'Governance refers to the emergence and change of institutions, of rules of the game. Governance thus includes the setting of rules, the application of rules, and the enforcements and adjudication of rules' (Kjaer 2003: 2). ${ }^{6}$

Gerry Stoker tries to find common ground in governance debates by listing five propositions that are not meant to be falsifiable or verifiable, but rather stand out as considerations:

1. Governance refers to a set of institutions and actors that are drawn from but also beyond government.

2. Governance identifies the blurring of boundaries and responsibilities for tackling social and economic issues.

3. Governance identifies the power dependence involved in the relationship between institutions involved in collective action.

4. Governance is about autonomous self-governing networks of actors.

5. Governance recognizes the capacity to get things done which does not rest on the power of government to command or use its authority. It sees government as able to use new tools and techniques to steer and guide (Stoker 1998: 18).

6 Scholars from the field of institutional economics, foremost among them Oliver Williamson, also deal with rules of the games in economic governance. They refer to them as "institutions" (Williamson 1995:171ff). 
Stoker's propositions embrace all three political dimensions: polity, politics and policy. His first proposition refers to the institutional structure of a state or multilevel governance system, the dimension of polity. Renate Mayntz, for instance, regards governance as being located in the polity dimension. For her, governance looks at a system of rules that forms social action (Mayntz 2004).

The dimension of politics describes processes of policy creation. For Beate Kohler-Koch, governance research deals primarily with political processes that translate divergent societal interests into political decisions (Kohler-Koch 1998: 11). Stoker's third and fourth considerations deal with this dimension.

Finally, the dimension of policy examines concrete political measures, their implementation and steering instruments. Adrienne Héritier defines governance as a 'mode of political steering' (Héritier 2002: 1). For her, governance deals with diverse steering instruments that can be applied in a more or less heavy-handed fashion. Examples for these different instruments can be command and control, incentives, information, deliberation or persuasion (Treib, Bähr and Falkner 2005: 5). This third dimension of politics is represented in Stoker's last proposition. This essay follows Stoker's propositions and regards governance as a concept that tries to analyse all three dimensions of political science.

\section{Categories of analysis}

On the basis of this assumption, Treib, Bähr and Falkner created a model of analysis that examines collective decision-making in nine categories (Treib, Bähr and Falkner 2005: 6). Each category locates so-called modes of governance on a spectrum between two extremes: state intervention and societal autonomy. These extremes must be labelled ideal modes as in reality there only exist hybrid modes. ${ }^{7}$ This study uses seven out of the original nine categories presented by Treib, Bähr and Falkner: ${ }^{8}$ three categories on the dimension of polity, one comprehensive category on the dimension of politics, and three categories on the dimension of policy.

1. Hierarchy versus market. This category analyses the institutional structure of a state or a political sector within a state. It asks whether the structure is hierarchical

7 The original model was created to examine modes of governance within the European Union, but I regard it as likewise useful for the analysis of collective decision-making at the state level in other regions of the world. However, I am well aware of ongoing discussions among regional studies scholars concerning the applicability of Western theories. I therefore tested each of the applied categories as it was embedded in the empirical context of each country.

8 I discarded two categories from the dimension of policy: 'fixed versus malleable norms' and 'rigid versus flexible approach of implementation'. This was done for the following reasons: firstly, categories are distributed more evenly if only three categories are applied to the dimension of policy. Secondly, the first of these two categories is described only vaguely. The second category - according to the authors-is closely related to categories four and seven and consequently merges with them. 
or market orientated. The first extreme describes one or a few actors being able to make decisions without the further approval of other actors. The latter refers to institutional settings that allow different actors to coexist and realise their own political ideas. Hybrid modes of institutional networks can be found between these two extremes (Treib, Bähr and Falkner 2005: 9). Central questions in this category are: how many and which actors are involved in decision-making? How do these actors coexist and do they create networks within the institutional structures? If yes, do these networks show tendencies towards one of the two extremes?

2. Central versus dispersed locus of authority. This second category is related to the first one, but asks rather for the dispersion of authority between central and local actors. ${ }^{9}$ Traditional modes in this category show a monopoly of central authority. Modern modes emphasise the inclusion of local actors in decision-making (Treib, Bähr and Falkner 2005: 9). ${ }^{10}$ Arun Agrawal and Maria Carmen Lemos point out the role of local actors in environmental governance: especially in terms of governing renewable resources a trend towards a dispersed locus of authority can be observed on a global scale (Agrawal and Lemos 2006). Research questions concerning this criterion are: how is authority in domestic climate change governance dispersed within a state? Does the central authority monopolise decision-making or are regional or local actors involved? Who are these actors and which role do they play?

3. Institutionalised versus non-institutionalised interactions. Formal institutionalisation of decision-making and political processes can differ from state to state. Interactions that define clear rules about who is involved in decision-making, how results shall be reached and who is responsible for monitoring compliance can be associated with traditional modes. Modern modes in this section include noninstitutionalised interactions with no constitutional foundation. These allow actors more flexibility. One example of this is the Open Method Coordination within the European Union (Treib, Bähr and Falkner 2005: 9). In this discussion, the question posed by this category is whether political decisions in domestic climate change governance in East Asia are based on clear constitutional rules. If yes, where do these interactions have a legal basis?

4. Only public actors involved versus only private actors involved. For Treib, Bähr and Falkner, the dimension of politics in governance research is mostly defined by the involvement of different kinds of actors. Traditional modes of governance show a hierarchical state leaving decision-making exclusively to public actors. Modern modes can be observed when only private actors such as organisations, compa-

9 This category can either refer to the horizontal (i.e. state actors in International Relations) or the vertical dimension of polity (i.e. territorial entities within a state). In this work it refers to the latter one.

10 Treib, Bähr and Falkner try to avoid labelling so-called old and new modes of governance. However, it has to be admitted that modes leaning towards state intervention tend to describe traditional modes, whereas modes showing signs of societal autonomy can be associated with modern modes that have emerged only within the last decades. 
nies or communities are involved in self-regulation without state intervention. Between these two extremes there are hybrid modes in which private and public actors build networks that can lean towards one of these extremes (Treib, Bähr and Falkner 2005: 8). Are non-state actors in Japan, China and South Korea involved in decision-making within climate change governance? If yes, who are these actors, how and to which extent are they involved and what kind of networks do they build with government? Is the role of NGOs confined to educational and informational work or are they involved in decision-making processes via networks?

5. Legal bindingness versus soft law. The policy dimension covers three categories of which the first one examines the legal bindingness of political measures. If policy outputs oblige private actors to pursue political reforms or install certain measures, Treib, Bähr and Falkner speak of legal bindingness. Soft law refers to modes that leave the implementation of measures to the respective actors. Nonbinding measures can be found in guidelines or recommendations. Political reality mostly provides hybrid modes (Treib, Bähr and Falkner 2005: 7). This category asks whether soft law instruments are used in domestic climate change governance in Japan, China and South Korea or whether legally binding measures prevail.

6. Presence versus absence of sanctions. Legally binding measures are often combined with the threat of sanctions when actors fail to comply. Sanctions can be of a financial or a penal nature or can concern the allocation of licenses. A modern mode of governance can be determined if the legislator refrains from the threat of sanctions in laws (Treib, Bähr and Falkner 2005: 8). Do the legislators of climate change laws in the respective states use sanctions to guarantee compliance? If the threat of sanctions is used, of what nature are these sanctions and how concisely are they defined in laws?

7. Material versus procedural regulation. This last category analyses the form of regulation within a measure. Detailed material standards within political measures such as quotas indicate traditional modes of governance. In environmental governance examples for material regulation are emission standards or energy efficiency standards. Procedural regulation on the other hand emphasises the establishment of procedures. It focuses on the process of implementation (Treib, Bähr and Falkner 2005: 8). Do East Asian states rather use material regulation in their climate change policies or do they focus on procedural regulation? What kind of material and procedural regulations can be found?

\section{Climate change policies in Japan, China and South Korea}

Japan's engagement in climate change policy did not start until 1992, when Japan prepared its accession to the UNFCCC. Like China and South Korea, Japan signed the Kyōto Protocol in 1998 and ratified it in 2002, but is still the only one out of all 
three countries to have set a fixed reduction target of 6 percent. 3.9 percent of this target was planned to be reduced in the LULUCF sector. No fixed quotas were planned for reductions of $\mathrm{CO}_{2}$ in the energy sector. Emissions of hydrofluorocarbons (HFC), perfluorocarbons (PFC) and sulfur hexafluoride $\left(\mathrm{SF}_{6}\right)$ were even allowed to rise by 2 percent (Shimizu 2004: 15). To attain its target the government passed the Act on Promotion of Global Warming Countermeasures ${ }^{11}$ in 1998 and later on, in 2005, the Kyōto Protocol Target Achievement Plan. ${ }^{12}$ Furthermore, there are several laws and regulations that include global warming measures in other sectors such as the forest or energy sector. One example of the latter is the Act on the Rational Use of Energy. ${ }^{13}$ The act was first implemented in 1979 and then subsequently revised. It served as an example for other countries and successfully reduced Japan's energy consumption per GDP (Shiel, Jeffers and Dyar 2011: 2). The Fifth National Communication to the UNFCCC shows all implemented measures in a summarised form (Government of Japan 2010: 170f).

The basic ideas behind the Japanese Climate Change Programme are the following: implementation of various policy instruments, the involvement of all sectors relevant to climate change, international co-operation for global participation, the creation of a low-carbon society and innovative technologies, the promotion of evaluation and review processes, as well as the integration of the economy and the environment. The government plans to adopt voluntary, regulatory, economic and informational instruments, taking advantage of their respective characteristics (Shimizu 2004: 7; Government of Japan 2010: 123f).

China implemented its first climate change measures within the Ten-point Policy for Environment and Development ${ }^{14}$ in 1992. The Ninth Five-Year Plan of 1996 set sustainable development as one of the top priorities. One year later, the government implemented the Law on Energy Conservation of the People's Republic of China. ${ }^{15}$ After the ratification of the Kyōto protocol in 1997, several further laws combining economic development and global warming countermeasures were passed (Central People's Government of the PRC 2004: 73ff). However, no comprehensive climate change programme existed until the government passed the National Climate Change Program ${ }^{16}$ in 2006 . This programme combines global warming countermeasures with a strategy of sustainable development and the building of a resourceconserving and environmentally friendly society. It emphasises energy conservation measures in the energy sector (National People's Congress of the PRC 2007). As

11 The act's name in Japanese is Chikyū ondanka taisaku no suishin ni kansuru hōritsu 地球温暖化対策の推 進に関する法律.

12 In Japanese: Kyōto giteisho mokuhyō tassei keikaku 京都議定書目標達成計画.

13 In Japanese: Enerugī no shiyō no gōrika ni kansuru hōritsu エネルギーの使用の合理化に関する法律.

14 In Chinese: Zhōngguó huánjìng yǔ fāzhăn yīng căiqǔ de shí dà duìcè 中国环境与发展应采取的十大对策.

15 Chinese title: Zhōnghuá rénmín gònghéguó jiéyuē néngyuán fã 中华人民共和国节约能源法.

16 In Chinese: Zhōngguó yīngduì qìhòu biànhuà guójiā fāng’àn 中国应对气候变化国家方案. 
Paul G. Harris points out, without external pressure the Chinese government would not have been interested in global warming countermeasures. He identifies three major interests: promoting economic growth, upholding the country's sovereignty, and improving China's national image (Harris 2003: 8). In this sense, most climate change laws and the national programme promote sustainable development. Georg Troost comments at this point that the Chinese government only uses the catchphrase 'sustainable development' rhetorically and in fact puts economic development at the forefront of the agenda (Troost 2000: 37f). However, the government implements global warming countermeasures in all relevant sectors, albeit with a strong focus on energy issues.

South Korea's climate change activities formally started with the establishment of the Inter-Ministerial Committee on the UNFCCC (IMC) ${ }^{17}$ in 1998. The first action plan for the period between 1998 and 2001 included 27 measures focusing on renewable energy and voluntary agreements with energy providers. The second action plan for the period between 2002 and 2004 emphasised the development of low-emission technologies, the promotion of greenhouse gas reduction measures and more involvement of the public. The third action plan included a shift towards more adaptation measures and an overall approach of mitigation measures throughout all sectors. After this third action plan, the Office of Government Policy Coordination ${ }^{18}$ evaluated that only 13 percent of industries actively took part in greenhouse gas reduction. This failure was said to be due mainly to a lack of national targets and negative attitudes towards climate change measures (Oh 2008: 486ff).

In 2008, the government initiated a new strategy leading to the Low Carbon, Green Growth Law that became effective in April 2010. Although being complementary to existing laws, this new strategy signifies a shift in many ways, in that the law combines energy policies with sustainable development and climate change. The president now heads the responsible Presidential Committee on Green Growth (PCGG) ${ }^{19}$ (Ministry of Government Legislation 2010b: 43). Many measures are binding and carry sanctions. In this sense they mean a change in modes of governance, as the analysis will show.

17 In Korean: Yuen kihu pyŏnhwa hyŏbyak changgwan hoeŭi 유엔기후변화협약 장관회의.

18 Korean title: Kungmu chojŏngsil 국무조정실.

19 In Korean: Noksaek sŏngjang wiwŏnhoe 녹색성장 위원회. 


\section{Analysis}

\section{Category 1: hierarchy versus market}

In Japan, official diction sees the central government as the sole authority to carry out climate change measures:

The national government has the role of comprehensively promoting global warming countermeasures and taking the initiative in implementing such countermeasures. Local governments, business operators and citizens are required to undertake the roles appropriate for their respective positions (Government of Japan 2010: 126).

Accordingly, non-state and local actors by and large are excluded from decisionmaking. The central decision-making body is the Global Warming Prevention Headquarters (GWPH). ${ }^{20}$ It consists of the prime minister, the cabinet chief secretary, the ministers of the Ministry of Economy, Trade and Industry (METI) ${ }^{21}$ and the Ministry of Environment $(\mathrm{MoE})^{22}$ as deputies, as well as all other state ministers as ordinary members. The GWPH prepares compliance with Kyōto Protocol targets, implements long-term measures, delegates responsibilities to local actors and passes guidelines, acts and laws (Government of Japan 1998; Fisher 2003: 193). According to Hattori Takashi, the METI and the MoE are willing to compromise in order to benefit successful implementation of measures within the GWPH (Hattori 2007: 83). There are other actors joining in climate change policy besides the GWPH: the Japan Central Environmental Council ${ }^{23}$ is an advisory organ on the highest level, consisting of non-state actors. It can propose measures, but is largely excluded from decision-making (Shimizu 2004: 18). The Japan Center on Climate Change Action $(\mathrm{JCCCA})^{24}$ is entrusted with informational work, educational training, co-ordination and research on the implementation of measures (Government of Japan 1998). Lastly, the Japanese Business Federation-Keidanren ${ }^{25}$ is a mediator and sets up voluntary agreements between companies and the government. It is also excluded from decision-making (Schreurs 2002: 243).

The institutional structure of climate change policy in Japan shows clear tendencies towards a hierarchical mode of governance, with the GWPH the sole decisionmaking body and holding full monopoly of power. Other actors do exist, but are

20 Its Japanese title is Chikyū ondanka taisaku suishin hombu 地球温暖化対策推進本部.

21 Japanese title: Keizai sangyō shō 経済産業省.

22 Japanese title: Kankyō shō 環境省.

23 In Japanese: Chūō kankyō shingikai 中央環境審議会.

24 Japanese: Zenkoku chikyū ondanka bōshi katsudō suishin sentā 全国地球温暖化防止活動推進センター.

25 Known in Japanese as Nippon keizai dantai rengōkai 日本経済団体連合会. 
entrusted with informational or advisory tasks as well as matters of co-ordination and implementation.

China shows a similar hierarchical setting without the involvement of other actors than the responsible decision-making body. State reforms have meant that the institutional structure of climate change mitigation policy in China has changed several times since the Kyōto conference.

Before 1998, environmental policy was institutionalised within the State Environmental Protection Administration (SEPA). ${ }^{26}$ The National Leading Group for Ozone Layer Protection ${ }^{27}$ was responsible for climate change policy within SEPA. In 1998, responsibility for climate change matters was shifted on to the National Development and Reform Commission (NDRC). ${ }^{28}$ According to Qi et al. this was 'an early symbol that climate change was no longer being treated simply as a science issue, but rather, as an issue of sustainable development' (Qi et al 2008: 381). The responsible decision-making body from 1998 onwards was the National Coordination Committee on Climate Change (NCCCC). ${ }^{29}$ This agency consisted of thirteen members, all of which were ministries, and was headed by the vice-prime minister. The last reform occurred in 2007, when the former NCCCC was divided into twin groups, the National Leading Group on Climate Change (NLGCC) ${ }^{30}$ and the National Leading Group on Energy Saving and Pollution Reduction. ${ }^{31}$ Both groups remain within the NDRC (Qi et al 2008: 381). These reforms had three major implications. Firstly, they strengthened the government's decision-making capacity in climate change policy. Secondly, they created a close tie between energy saving and climate change. Thirdly, by involving the NDRC, the government emphasised the role of actors who are development oriented. The reforms thus stress the coexistence of environmental protection and economic development (Heggelund 2007: 174; Zhao 2005: 3). Of non-state actors, only scientific boards are integrated into the institutional structure and have certain decision-making powers (see category 4).

The leading institution in South Korean climate change polity is the IMC, founded in 1998. It is headed by the prime minister. Its members are ministers, governmental agencies, experts and industry representatives. For example, the National Institute of Environmental Research ${ }^{32}$ and the National Institute of Meteorological Research $^{33}$ represent the scientific community. The Korean Chamber of Commerce

26 In Chinese: Zhōngguó guójiā huánjìng băohù zǒngjú 中国国家环境保护总局.

27 In Chinese: Guójiā băohù chòuyăng lǐngdăo xiăozǔ 国家保护臭氧领导小组.

28 Known in Chinese as Guójiā fāzhăn hé găigé wěiyuánhuì 国家发展和改革委员会.

29 The Chinese name is Guójiā qìhòu biànhuà duìcè xiétiáo wěiyuánhuì 国家气候变化对策协调委员会.

30 Known in Chinese as Guójiā yīngduì qìhòu biànhuà lǐngdăo xiăozŭ 国家应对气候变化领导小组.

31 Known in Chinese as Jiénéng jiănpái gōngzuò lǐngdăo xiăozǔ 节能减排工作领导小组.

32 Korean title: Kungnip hwan'gyŏng kwahagwŏn 국립환경과학원.

33 In Korean: Kungnip kisang yŏn'guso 국립기상연구소. 
and Industry ${ }^{34}$ represents industry. The committee's main tasks are working out, coordinating and implementing comprehensive action plans every third year and preparing national reports to the UNFCCC (Oh 2008: 487f). In September 2001, the Vice-Ministerial Committee was added to the institutional structure. Now the institutional landscape consisted of two committees, six working groups and five expert teams. Non-state actors joined working groups and expert teams (Choi 2004: 7). In 2010, the Presidential Committee on Green Growth was founded as part of the new Low Carbon, Green Growth Strategy (Ministry of Government Legislation 2010b: 43). This can be seen as a clear shift towards an institutional structure more focused on sustainable development. It is not yet clear what role the PCGG will play in the future and whether it will take the place of the IMC in the long run.

The institutional structures show tendencies towards networks between various types of actors. No reports of power struggles or quarrels about competencies could be found. However, literature on this topic is scarce. Yet it must be assumed that the South Korean Ministry of Environment ${ }^{35}$ plays a strong role. It developed most of the relevant climate change laws and constitutes itself as the main actor in climate change policy:

The Ministry of Environment has positively joined in the international efforts to prevent global warming and has carried out diverse policies to reduce GHG [Greenhouse gas emissions] in response to the UNFCCC. In addition, it has worked out systematic long and short-term strategies including negotiation strategies to protect the domestic industry (Ministry of Environment of the ROK 2011)

Whether the institutional shift described above will have consequences for the power relations between the networks has yet to be observed.

\section{Category 2: central versus dispersed locus of authority}

Officially, the central government in Japan encourages local governments to develop and implement action plans in order to reduce greenhouse gas emissions locally, especially in the sectors of renewable energy, waste and transport (Government of Japan 2010: 127, 186). Local initiatives in environmental politics have been a long tradition since the 1940s. Cities like Kyōto 京都 and Tōkyō 東京 have implemented various projects to reduce emissions. The project Carbon-Minus Tōkyō ${ }^{36}$ aimed at a 25 percent reduction in the greenhouse gas emissions of the year 2000 by 2010 . Japanese cities are also taking part widely in transnational networks such as the International Council for Local Environmental Initiatives programme (ICLEI)

34 In Korean: Taehan sanggong hoeŭiso 대한상공회의소.

35 Korean title: Hwan'gyŏngbu 환경부.

36 In Japanese: Kābon mainasu tōkyō カーボンマイナス東京. 
(Schreurs 2008: 351; Schreurs 2009: 17). Initiatives are taken especially in the sectors of transport and waste. The city of Nagoya 名古屋 offers discounts on metro tickets and promotes low-emission means of transportation. Local action might also be adopted by the national government. After the government of Kyōto introduced restrictive energy conservancy measures, they were included in the 2008 revision of the Act on the Rational Use of Energy (Sugiyama and Takeuchi 2008: 431f).

However, local actors' competencies and responsibilities are limited to the formulation of action plans and educational tasks (Sugiyama and Takeuchi 2008: 424). As Schreurs puts it, local actors are basically expected to carry out central policies, but can take action in fields where the central government has not yet acted (Schreurs 2008: 345). In this sense, action still remains in the hand of the central government. Yet certain freedoms are granted to local actors.

Until recently, Chinese climate change policies were mainly developed and implemented by the central government, with local actors widely excluded from decision-making and self-initiative. It was not until 2007 that Běijīng 北京 issued a directive encouraging provinces to establish task forces and initiate concrete action at sub-state level (Central People's Government of the PRC 2007). Eight provinces and autonomous regions founded local Leading Groups on Climate Change modelled on the central government's example. The others established task forces with a special focus on energy efficiency. Targets and measures were formulated according to local circumstances. Task forces were mostly entrusted with evaluation work, the promotion of scientific research and the implementation of state measures. Only a few provinces were assigned to elaborate legislative measures in the field of energy efficiency (Qi et al. 2008: 385ff). Therefore, despite obvious decentralisation measures, the autonomy of local authorities is still limited. Arthur P.J. Mol and Neil T. Carter as well as Jonathan Schwartz see these developments as part of an overall strategy in environmental politics: such measures neither mean a loss of power for the state nor do they give real autonomy to the provinces. In this way, the state still controls access to resources, technologies, information and finances. Although the state releases control on the micro-level, it still remains control on the macro-level (Schwartz 2004: 28; Mol and Carter 2007: 8).

Local autonomy in South Korea has increased since decentralisation efforts were launched from 1995 onwards. Local actors tackled many environmental issues within Agenda 21, ${ }^{37}$ with 90 percent of all local governments taking part in various projects. However, some agendas encountered financial problems and focused on economic development rather than on solving environmental problems (Moon 2004).

In climate change politics, the state entrusted local governments with diverse tasks. Besides implementing projects, enforcing laws and carrying out educational 
and informational projects (Government of the ROK 2003: 12, 20, 57, 64f), local governments also had the chance to autonomously work out and implement action plans. Sixteen cities developed measures in the following sectors: renewable energy, transportation planning, education and public relations. Each city could freely set reduction targets and did not have to report to the central government. Yet financial support differed heavily from city to city. Whereas Seoul 서울 was granted 600 million won, Ulsan 울산 received a budget of only 10 million won. Up to 2008, ten out of sixteen cities successfully implemented action plans (Green Korea United 2008). In terms of co-operation with transnational networks, South Korean cities also played a major role: thirty-five cities and regions took part in the ICLEI program. Compared to 20 in Japan and one in China, this is the highest number in the region (Schreurs 2009: 21). The new strategy of 2010 seems to strengthen local actors' decision-making power: according to Article 11/1 of the new law, cities should freely develop and implement local action plan (Ministry of Government Legislation 2010a: 97). However, the law does not go into detail about financial resources. Whether the new strategy really means an increase in autonomy for local actors remains to be seen.

\section{Category 3: institutionalised versus non-institutionalised interactions}

The main Japanese climate change laws clearly describe actors and the circumstances of decision-making as well as tasks of co-ordination and evaluation. The Act on Promotion of Global Warming Countermeasures serves here as an example of how lawmakers define the framework of implementation. The act determines responsibilities between local and central actors, the public and businesses as well as within the institutional frame of GWPH. Article 20 deals with ways of decisionmaking at the national level, Article 21 with the process at prefectural and communal level. Modes of implementation and notification are defined in Chapters 3 and 4 of the same article. Article 11 assigns to the GWPH the co-ordination of all responsibilities. The JCCCA is mandated with co-ordinating measures at prefectural level in Article 25. Finally, the task of monitoring implementation is directed to the central government in Article 2 of Chapter 6 (Government of Japan 1998). As this example shows, all interactions are institutionalised. This reflects a traditional mode, according to Treib, Bähr and Falkner.

Unlike Japan, China did not pass laws that dealt solely with global warming countermeasures before 2007. Yet, not even the National Climate Change Programme defines a legal foundation for the institutional structure. Interactions, therefore, were not institutionalised via laws but via other forms such as decrees or notifications of official institutions: one example is the transformation of the NCCCC into the NLGCC by the State Council in 2007. Notification No. 18 of 2007 defines the 
authority in decision-making and responsibilities for monitoring and coordination (Central People's Government of the PRC 2007). Although the notification elaborates comprehensively on the interactions, it cannot be considered as a constitutional foundation and therefore does not fit Treib, Bähr and Falkner's definition of traditional modes.

The 2010 Framework Act on Low Carbon, Green Growth is the first comprehensive South Korean law to set global warming countermeasures as primary (if not sole) targets. The institutional framework as well as tasks and responsibilities are clearly defined in Articles 10 to 15 of the correspondent Enforcement Decree. Chapter 5 assigns further power to the PCGG. Monitoring and control modes are defined in Chapter 5, Articles 27 and 28 (Ministry of Government Legislation 2010a: 110ff). Whereas the new strategy clearly institutionalises all interactions, earlier laws did not do this in a similar way. Only the 1997 Environmental Impact Assessment Act ${ }^{38}$ clearly determines who implements measures and who is charged with monitoring (Ministry of Government Legislation 2009).

\section{Category 4: only public actors involved versus only private actors involved}

This section analyses the forms of organisation between non-state and state actors in Japanese, Chinese and South Korean climate change politics. Despite playing a rather weak part in general, civil society in Japan developed an active role in environmental issues in post-war Japan, when river pollution led to uproar and activism among citizens. In particular, the Minimata diseases ${ }^{39}$ in the 1950 s and 1960s, caused by mercury pollution, triggered local grassroot environmental movements (Almeida and Stearns 1998). The number of climate change-related NGOs rose after the Kyōto conference in 1997, with seventy organisations joining forces and founding the Kiko Forum, ${ }^{40}$ later renamed the Kiko Network. ${ }^{41}$ It set itself to inform citizens about the consequences of global warming, to organise conferences and research seminars as well as to issue policy papers (Schreurs 2002: 220). Another active organisation is WWF Japan ${ }^{42}$ which-besides informational work-cooperates with industrial companies and offers help in developing policy papers for the government (Fisher 2003: 198). Yet, Japanese civil society is rather weak in environmental protection and climate change, and organisations lack resources and networks with politics and businesses. They are widely excluded from decision-

\footnotetext{
38 Korean name: Hwan'gyŏng yŏnghyangp'yŏng kabŏp 환경영향평가법.

39 In Japanese: Minamata byō 水俣病.

40 Its Japanese title is Kikō fōramu 気候フォーラム.

41 Japanese title: Kikō nettowāku 気候ネットワーク.

42 Its Japanese form is WWF ジャパン.
} 
making processes. Besides, NGOs are only sparsely interconnected: Kiko Network, for example, does not co-operate with organisations from other relevant sectors like nuclear energy (Foljanty-Jost 2005: 114). Moreover, civil society's interest in climate change issues is rather limited: NGOs experience difficulties to communicate this rather complex issue to citizens (Fisher 2003: 198). Many organisations focus more on the local than on the national level. Local initiatives, for example, do informational work on energy saving and efficiency. They are financially more autonomous and act independently from domestic climate change policy (Fisher 2003: 199).

Japanese companies are much more closely connected to the government than are civil society actors. Co-operation between state and industry has a long tradition in Japan. Nowadays, the industrial association Keidanren co-ordinates all forms of co-operation concerning climate change. It has also negotiated voluntary agreements between state and industry. Although voluntary on paper, many companies feel pressured to agree to such contracts (Fisher 2003: 196). In general, the government expects companies to implement and promote global warming countermeasures, but does not give them chances to initiate measures on their own (Government of Japan 2010: 127). Concerning the whole process of decision-making, Harris rightly states: '[...] Japanese policy on climate change is largely the result of bargaining among state-level actors (i.e. bureaucrats and the ruling party) in association with Japanese industry' (Harris 2003: 7).

Political restrictions and hindrances mean that non-state actors have a low influence on Chinese environmental politics. Mol and Carter name three categories of actors which - to a certain extent-participate in political processes: major transnational enterprises, environmental industry companies, and research institutions (Mol and Carter 2007: 11). In climate change civil society structures there are two major forms of NGOs: officially accepted NGOs, and governmentoperated NGOs (GONGOs). ${ }^{43}$ NGOs are tightly controlled by the government and their influence is limited to educational and informational work. Financial resources are scarce. They operate predominately at local levels. Their work, therefore, can hardly be compared to that of Western pressure groups (Schwartz 2004: 10; Mol and Carter 2007: 12). Yet, greater independence in recent years, increased participation in international networks and even endorsement by the government give hope for a more important role in the future (Richerzhagen and Scholz 2007: 319). One example of NGOs' increased co-operation with international organisations is the 2009 petition by the Chinese Civil Society on Climate Change (CCSCCC) ${ }^{44}$ that included twelve policy propositions directed towards the Chinese government. It was signed by eight Chinese and various international NGOs (CCSCCC 2009).

43 In Chinese: Zhèngfǔ zhǔdăo xiàde shètuán zǔzhī 政府主导下的社团组织.

44 In Chinese: Zhōngguó gōngmín shèhuì yīngduì qìhòubiànhuà lìchăng 中国公民社会应对气候变化立场. 
GONGOs are more influential than NGOs. They derive financial and personal backing from the state, but are less independent. Important GONGOs in China are the China Environmental Protection Foundation ${ }^{45}$ and the Centre for Environmental Education and Communications. ${ }^{46}$ As they have scientific expertise, they can both influence decision-making processes. Yet their main work is limited to educational training, as well as international exchange (Schwartz 2004: 15).

The only non-state actors to be involved to a considerable extent in decisionmaking are scientific bodies and organisations. Here, two groups must be distinguished. The first group covers natural scientists dealing with causes and consequences of climate change. The second, much smaller group includes social scientists. Both groups have strong ties with the government. Examples are the Energy Research Institute ${ }^{47}$ and the Research Centre for Sustainable Development ${ }^{48}$ of the Chinese Academy of Social Sciences. ${ }^{49}$ As both are integrated into the NLGCC and are therefore part of the institutional structure, it can be said that they are the only non-state actors with real influence on decision-making (Richerzhagen and Scholz 2007: 316).

Businesses have only limited influence on processes in climate change politics. Only state-owned and partly state-owned companies from energy-intense sectors like cement or steel might be included in decision-making by the central government. In other sectors, involvement by companies depends on whether the government is interested in participation by the relevant industries (Richerzhagen und Scholz 2007: 319; Zhao 2005: 75).

South Korea has a short, but rich history of civil society participation. After the democratisation movement of 1987, civil society organisations spread throughout many political and societal spheres (Kim 2000: 4). From the mid-1990s onwards, the government realised that participation by civil society could also be of use in environmental politics and therefore set the course for public-private networks, such as the Central Environmental Conservation Council (CECC) ${ }^{50}$ an advisory board in which nine out of twenty-three members are non-governmental (Jeong 2002: 50). Networks like CECC help the government to make up for resource deficits and to maintain close ties with citizens. Yet the government never passes decision-making authority to NGOs (Jeong 2002: 48).

Climate change NGOs are numerous and often act as pressure groups. The Korean Foundation for Environmental Movement (KFEM), ${ }^{51}$ founded in 1993, is one

45 The Chinese title is Zhōnghuá huánjìng băohù jījīnhuì 中华环境保护基金会.

46 In Chinese: Huánjìng bǎohù bù xuānchuán jiàoyù zhōngxīn 环境保护部宣传教育中心.

47 The Chinese title is Néngyuán yánjiūsuǒ 能源研究所.

48 In Chinese: Kěchíxù fāzhăn yánjiū zhōngxīn 可持续发展研究中心.

49 Known in Chinese as Zhōngguó shèhuì kēxuéyuàn 中国社会科学院.

50 In Korean: Chungang hwan'gyŏng pojŏn hyŏbŭihoe 중앙 환경보전 협의회.

51 Its Korean title is: Hwan'gyŏng undong yŏnhap 환경운동연합. 
of the biggest environmental NGOs and is very active in climate change. It has about 85,000 members, maintains forty-seven offices throughout the country and primarily works on climate change education and international co-operation. It is prepared to confront the government directly (Green Assembly Asia Environment 2010). KFEM is especially active in the energy sector and aims at establishing an energy-saving culture in South Korea. Common projects and networks exist between the state and NGOs as, for example, the Energy Winner Prize, ${ }^{52}$ a project of the Ministry of Industry and Resources, ${ }^{53}$ the Ministry of Environment and various NGOs (Lee and Bückmann 2007: 286). In sum, although civil society organisations are engaged actively and play a lively part, their role is still limited in decision-making.

Businesses used to be actively involved via voluntary agreements between industry and the state, but as the new strategy of 2010 does not include such provision, they only play a minor role (Ministry of Government Legislation 2010b: 28). In short, through political culture and institutional structures non-state actors are more present and have greater influence in climate change politics than in Japan or China; but their impact is often confined to educational and informational work.

\section{Category 5: legal bindingness versus soft law}

The Japanese government has implemented various measures via diverse steering instruments. Non-binding measures do exist, but the majority of implemented measures are of a binding nature. Voluntary agreements between state and industry are non-binding measures, but these agreements put heavy pressure on the respective companies (Government of Japan 2010: 138). Furthermore, the government has implemented guidelines as part of the Education for Sustainable Development programme. ${ }^{54}$ Apart from these two instances, no further non-binding measures have been found. All measures within laws and directives are of a binding nature. The government has primarily implemented mandatory standards such as the introduction of a maximum speed in order to reduce $\mathrm{CO}_{2}$ emissions or minimal standards for energy devices within the Top Runner Programme ${ }^{55}$ (Government of Japan 2010: 154; Nordqvist 2006: 13). Further binding measures, for example, are caps for high-emission fuel or obligatory standards for fertilisers (Government of Japan 2010: 153, 166). Binding measures can be found across all sectors of climate change policy and clearly outweigh non-binding measures.

Within this study, no non-binding measures could be found in China's measures in the field of climate change policy. Binding measures in the transport sector in-

52 In Korean: Enŏjisang susang 에너지상 수상.

53 Its Korean title is Sanŏp chawŏnbu 산업자원부.

54 In Japanese: Jizoku kanō na kaihatsu no tame no kyōiku 持続可能な開発のための教育.

55 Known in Japanese as Toppu rannā hōshiki トップランナー方式. 
clude the obligation to use energy-saving products in the car and shipping industries and standards that control maximum emissions of engines (Central People's Government of the PRC 2004: 111). Likewise, measures in the energy sector were of a binding nature without any exception: for instance, small and inefficient coal power stations were shut down to reduce emissions. Moreover, a labelling system for electrical and mechanical products was introduced to promote energy efficiency (Central People's Government of the PRC 2004: 102, 111). The government furthermore introduced design standards such as the mandatory use of low-emission fans or insulation material in the construction sector or quotas on energy usage as well as the abolition of high-emission material in industrial companies (Central People's Government of the PRC 2004: 103). Lastly, binding directives in the waste sector were implemented to regulate the content of methane in the air within landfill areas (Central People's Government of the PRC 2004: 123).

South Korea's measures show two different pictures in terms of non-binding measures for the given time frame. Whereas the 2003 national report to the UNFCCC still shows a high volume of non-binding measures, their number is significantly lower in the Low Carbon, Green Growth Strategy of 2010. Binding measures in the national report include obligatory standards in the construction sector, forestry sector and transport sector (Government of the ROK 2003: 47, 49, 50). Non-binding measures can most often be found in guidelines and recommendations, of which the report contains several: the government passed various guidelines, for instance, in order to control energy efficiency in public buildings and minimise the amount of waste in factories (Government of the ROK 2003: 51, 55). Guidelines are furthermore part of the Green Building Certification Programme ${ }^{56}$ and aim at introducing low-emission construction materials (Government of the ROK 2003: 59). Recommendations were used for Agenda 21 or in the forestry sector to urge companies to reduce emissions (Government of the ROK 2003: 116, 119). Lastly, voluntary agreements between state and industry are also non-binding measures (Lee and Bückmann 2007: 280). Surprisingly, the Low Carbon, Green Growth Strategy of 2010 by and large renounces non-binding measures. Guidelines and recommendations are low in number. Binding measures predominate throughout all sectors. Several types of standards exist for various processes in the construction sector (Ministry of Government Legislation 2010b: 56, 77). In sum, South Korea showed a mix of binding and non-binding measures before 2010 , with guidelines especially predominating. The government brought about a change within the new law by installing binding measures. 


\section{Category 6: presence versus absence of sanctions}

The Japanese government applies sanctions in the Act on Promotion of Global Warming Countermeasures and other laws that contain climate change policies. Articles 48 to 50 of the first define penalties in case of non-adherence. Most of these sanctions are aimed at actors that fail to show compliance with reduction programmes. For example, Article 48 makes individuals as well as companies responsible. Sanctions in this case range from 200,000 to 500,000 yen. Still, sanctions are rather vaguely described in this act (Government of Japan 1998). Other laws are more detailed and nuanced in the definition of sanctions. The Act on the Rational Use of Energy sets out detailed penalties for companies offending against energy efficiency standards. Sanctions range from fines between 200,000 and one million yen and sentences of up to one year in prison (Government of Japan 2005a). Another example is the Act on Regulation, etc. of Emissions from Non-road Special Motor Vehicles ${ }^{57}$ aimed at actors that do not adhere to technical standards (Government of Japan 2005b). However, measures without sanctions also exist. With the introduction of non-binding programmes the number of measures lacking sanctions rose. In the case of the Top Runner Programme, the government has abandoned fines and other penal action; rather, it pressures companies by threatening to publicly proclaim the company's name in case of non-adherence. These name-and-shame sanctions seem to be effective, as no cases of non-adherence were reported up to 2006 (Nordqvist 2006: 21).

The Chinese government clearly defines sanctions in all the relevant laws and regulations examined. There are no measures that point to legislation without sanctions. Most of the laws include fines and leave enforcement to the executing authority. Sanctions are mild in most cases compared to the heavy punishment traditionally applied in environmental legislation (Troost 2000: 31; Schwartz 2004: 31). The Renewable Energy Law of the People's Republic of China, ${ }^{58}$ for instance, imposes legal administrative penalties against power grid enterprises if they fail to purchase renewable power. Furthermore, enterprises in natural gas pipeline networks that do not permit the connection of natural gas to the network are confronted with fines (National People's Congress of the PRC 2005). The Forestation Law of the People's Republic of China ${ }^{59}$ punishes violation, i.e. if afforested stand is damaged or if afforestation projects are actively hindered. In this instance, violators are forced to participate actively in afforestation projects (National People's Congress of the PRC 1998). A third example of possible sanctions is provided by the Law on Energy

57 In Japanese: Tokutei tokushu jidōsha haishutsu gasu no kisei nado ni kansuru hōritsu 特定特殊自動車排 出ガスの規制等に関する法律.

58 In Chinese: Zhōnghuá rénmín gònghéguó kězàishēng néngyuán fã 中华人民共和国可再生能源法.

59 Its Chinese title is Zhōnghuá rénmín gònghéguó sēnlín fã 中华人民共和国森林法. 
Conservation, which imposes fines on companies selling products that violate the law. Sanctions here are not only of a financial nature, but can also mean the confiscation of the products or the withdrawal of selling concessions (National People's Congress of the PRC 1997).

The history of sanctions in South Korean climate change measures must be divided into two periods, the time before and after the introduction of the new strategy. Before 2010, laws and regulations involved severe sanctions, but many guidelines and recommendations also existed that lacked clear sanctions. Examples are the E-standby programme ${ }^{60}$ of 1999 or the High-Efficiency Energy Using Appliance Certification Programme ${ }^{61}$ of 1996. Laws that impose sanctions among others include the Rational Energy Utilisation Act ${ }^{62}$ from 1997. If companies oppose inspection of devices and machines or offend against labelling and licensing regulations, fines of up to 10 million won can be imposed. Companies that do not adhere to maximal standards will be punished with fines of up to 20 million won (Ministry of Government Legislation 1997). The 2007 Waste Law ${ }^{63}$ likewise sets sanctions for violations of the law. If individuals trade waste without license or dispose of waste illegally, they can be imprisoned for a maximum of five years or fined up to 50 million won (Ministry of Government Legislation 2007: 25). The new strategy of 2010 has brought about reduction targets in the industry, energy efficiency and renewable energy sectors. Heavy fines can be imposed if actors offend against their duties of reporting and fulfilment. Fines go by a four-level penal system, ranging from three up to ten million won (Ministry of Government Legislation 2010a: 142; 2010b: 84). As a consequence of a lack of guidelines and recommendations within the new law, a clear shift in the allocation of sanctions can be observed. Whereas a mix of sanctioned and non-sanctioned measures existed before 2010, all measures within the new strategy include sanctions.

\section{Category 7: material versus procedural regulation}

This category examines whether measures are subject to material or procedural regulation. In the case of Japan, material regulation clearly outweighs procedural regulation. Cases of the first can be found in every sector. The Japanese government introduced emission standards and speed limits in the transport sector, standards controlling $\mathrm{N}_{2} \mathrm{O}$ emissions in incineration facilities for waste or sewage sludge, as well as standards emphasising the reduction of energy use in household devices (Government of Japan 2010: 142, 154, 166). One example of the last is the introduction of

60 In Korean: Taegi chŏllyŏk chŏgam p'ŭrogŭraem 대기전력 저감 프로그램.

61 Its Korean title is Kohyoyul enŏji sayong injŭng chedo 고효율 에너지 사용 인증제도.

62 In Korean: Enŏji iyong hamni hwabŏp 에너지이용 합리화법.

63 Termed P'yegi mulbŏp 폐기물법 in Korean. 
the Top Runner Programme which sets minimal standards in eighteen product fields. Savings due to these standards were estimated to form up to 25 percent of the entire national savings target by 2010 (Nordqvist 2006: 6). Material regulation thus still seems to predominate for Japanese decision-makers. However, examples of procedural regulation do exist, such as within the guidelines for calculating $\mathrm{CO}_{2}$ emissions in the logistic field (Government of Japan 2010: 156). But as guidelines and recommendations are rare within all sectors, procedural regulation is hard to find in Japanese global warming countermeasures.

Similarly to Japan, China's climate change policies display material standards in every sector. China is the only country analysed that holds an institute for coordinating and implementing standards, the China National Institute for Standardisation (CNIS). ${ }^{64}$ Standards are especially prominent in the energy sector, where they include industrial boilers, motors, water pumps, and household appliances such as fans or refrigerators (Central People's Government of the PRC 2004: 95). For the last category CNIS introduced a labelling system which-according to Lin Jiangsaved 87 billion KwH of energy between 1989 and 1999, equalling a reduction of up to 15 percent (Lin 2002: 357). As Lin elaborates, material standards in the energy sector not only help to achieve reductions in emissions, but also stimulate one of the largest appliance markets (Lin 2002: 349). In this sense material regulation creates positive externalities for the economy and is therefore seen as a rational tool. Besides energy, standards were also widely present in the transport, construction, waste and agriculture sectors (Central People's Government of the PRC 2004: 110, 111, $115,123)$. Compared to material standards, procedural regulation is low in volume and predominantly exists within campaigns that aim at informing citizens about climate change issues (Central People's Government of the PRC 2004: 110). In a nutshell, material regulation clearly outweighs procedural regulation in all sectors.

Contrary to China and Japan, the number of material standards in South Korea's national report to the UNFCCC is rather low. Examples prevail in the energy sector, where the government introduced minimum standards in eighteen product fields to promote energy-efficient products. Moreover, target standards exist and guarantee certain savings within a range of time (Lee and Bückmann 2007: 278). Other than that, procedural regulation predominates. Afforestation projects, landfill gas extraction projects or control plans against forest pests all give priority to the process of implementation (Government of the ROK 2003: 57, 64). However, the Low Carbon, Green Growth Strategy ushered in a new period of regulation in Korean climate change policy, with the government introducing a large number of licenses, standards and targets. The latter were set to reduce greenhouse gases in the energy sector and to promote renewable energies. Licenses were introduced to feature green technology. Design standards exist for different stages of construction processes (Minis- 
try of Government Legislation 2010b: 56, 64, 77). Furthermore, the new law transformed formerly voluntary measures into binding norms that feature material standards. For the first time, industries are forced to stick to reduction targets and emission limits (Ministry of Government Legislation 2010a: 91). In short, due to the new strategy, modes of regulation have clearly shifted towards material regulation.

\section{Summary}

This concluding section summarises and compares the empirical findings of all categories in each of the three dimensions polity, politics and policy. At the end I will address the research question and verify or disprove the hypothesis.

The first category deals with the institutional structure of climate change politics in each of the three states. In Japan, the GWPH is the central actor in decisionmaking. Headed by the prime minister, METI and MoE have major competencies within the GWPH. Non-state actors are integrated into the institutional structure, but their influence on decision-making is limited. Therefore, Japan's institutional structure is clearly hierarchical. China shows a similar mode in this category. Despite frequent shifts, there has always been one single ministry as the leading decisionmaker within the responsible institution. At the moment, the NLGCC is the leading institution within the NDRC. Non-state actors are widely excluded from the structure. The institutional setting in China must be classified as exclusive, and it tends to a hierarchical mode on the spectrum of analysis. South Korea's setting deviates from those of China and Japan: The leading institution, the IMC, embraces various agencies and ministries as well as non-state actors. Still, the MoE seems to have major decision-making power. As South Korea's institutional setting shows tendencies towards structural networks, a somewhat hybrid mode of governance prevails.

The second category of analysis asks how authority is dispersed between local and central actors. In Japan, local governments do have certain competencies to freely develop and implement climate change initiatives in sectors like waste or transport. Still, local influence remains limited as it is mostly confined to educational and informational work. For this category, Japan shows a hybrid picture with strong tendencies towards hierarchical modes. Local Chinese authorities barely had any influence on decision-making until 2007, and even now, the central government controls resources and retains decision-making power. Here, modes of governance clearly tend towards hierarchical ones. South Korea shows the greatest extent of local autonomy, even if it is yet unclear to what extent authorities remain independent in decision-making after the implementation of the new strategy. Whereas Japan and China show congruent modes, South Korea deviates towards more hybrid modes. 
The third category deals with the institutionalisation of interactions. In Japan, the government fixed all interactions in the major climate change law, whereas China only pronounced the circumstances of a new institutional setting in a state council declaration. South Korea did not institutionalise interactions in a climate change law until 2010. The picture here is therefore not as clear as in previous categories.

The fourth category measures the involvement of non-state actors in political processes. Japan's civil society is only marginally included in decision-making. Networks between NGOs and politicians do not exist. Industries, however, are more involved via voluntary agreements, but their influence is also limited. In this sense, Japan tends towards rather hierarchical modes of governance. In China, the involvement of non-state actors is similarly limited; only scientific bodies are embedded in the institutional setting. The state maintains strict control over NGOs. GONGOs might be included when the government allows them to participate. As South Korea's environmental civil society has a longer history, networks between NGOs and the state do exist, and civil society organisations can even function as pressure groups. In sum, while Japan and China show similar hierarchical modes, South Korea's processes in climate change politics are characterised by hybrid modes.

The fifth category examines whether climate change laws are binding in nature or act rather as guidelines or recommendations. In Japan, binding measures predominate. Only a few guidelines and voluntary agreements exist. China's national report to the UNFCCC did not include any non-binding measures. In this sense, both countries show congruent hierarchical modes of governance. South Korea implemented the highest number of non-binding measures. The new strategy of 2010, however, suggests a shift towards a more traditional mode, as the number of guidelines and recommendation decreases.

The sixth category deals with sanctions within the measures. Japan's climate change laws mostly include clearly defined sanctions. In China, no climate change laws exist without sanctions. South Korea's laws also clearly formulate sanctions in the case of non-adherence, but the number of guidelines and other measures without sanctions is much higher than in Japan or China. Therefore South Korea shows a mix of measures with and without sanctions. Here, a hybrid mode of governance predominates.

The seventh and last category examines climate change policies on whether material regulation or procedural regulation prevails. In the case of Japan, various material standards exist-especially in energy saving, transportation, agriculture and waste. As hardly any cases with procedural regulation can be found, a hierarchical mode of governance is localised in this category. China has also implemented many measures promoting material standards. Procedural regulation only exists in educational campaigns. Contrary to the traditional modes in Japan and China, South Korea did not implement many material standards until 2010. The new strategy increases 
the number of material regulation measures. Therefore South Korea has shifted from hybrid modes towards hierarchical modes since 2010.

Regarding the three political dimensions of polity, politics and policy, the analysis illustrates the following results: on the dimension of polity, Japan and China show similar modes of governance, both to be localised on the traditional side of hierarchical modes of governance. South Korea deviates as it gives more autonomy to local and non-state actors. On the dimension of politics, the modes are similar: China and Japan both widely exclude non-state actors. South Korea-as the only state analysed — promotes public-private networks, but the central government is still the dominating actor. Here, Japan and China show traditional modes, South Korea tends towards hybrid modes. The dimension of policy features a similar picture: China's and Japan's measures are predominantly non-binding and incorporate sanctions and material standards. In this sense, they resemble a traditional mode of governance. Korea's measures before 2010 show hybrid modes on this dimension. The new strategy brought about a shift towards more traditional modes. Of all categories, only the third category shows results that do not point towards a clear divide between Japan and China on one side and South Korea on the other side.

With regard to the research question, I can make a clear point: modes of climate change governance in Japan, China and South Korea are not congruent. While Japan and China show striking similarities, South Korea features hybrid rather than hierarchical modes for the time up to 2010. The new strategies of Low Carbon, Green Growth brought about a shift in the direction of traditional modes. However, one cannot speak of a common East Asian model in domestic climate change governance for the given time frame. Likewise, the hypothesis must be regarded as disproved. Yet shifts in Korean modes might lead to congruent modes in all three states. Future analyses need to embed these new developments into a broader picture of a regional mode of climate change governance.

Strikingly, for the given time frame the governing modes of Japan and China show strong similarities and not_as might be supposed-Japan and South Korea. Unlike China, these two states share similar political systems and socio-economic developments, which might lead to the assumption that governance modes likewise would coincide. However, South Korea features more hybrid and open modes of governance that can be traced to stronger degrees of decentralisation and a more open civil society which found fertile ground on which to develop after the democratisation movement of 1987. Such developments cannot be observed in Japan and China. Although their political systems are diametrically opposed (autocratic vs. democratic), both states share common features of a strong state, centralised decision-making power and a weak civil society. This leads to the conclusion that hierarchical modes of governance do not depend on systemic criteria, but rather on the constitution of the state, as well as on power and resource allocation within state institutions. 
As literature is still scarce in this field, I can best hope that my work will serve as a point of departure for more research on climate change governance in East Asia. Besides a proper analysis of the consequences of Korea's new strategy, other aspects of East Asian climate change politics still remain unfamiliar territory for researchers. In this sense, research could be extended to other nations within the region. It could focus on local and intermediate levels in more detail and examine the influence of transnational networks on central action. Furthermore, as this work has mainly focused on formal politics, further research could include informal politics and thus create a more comprehensive picture of climate change governance in East Asia. 


\section{REFERENCES}

Agrawal, Arun, and Maria Carmen Lemos. "Environmental Governance.” In Annual Review of Environment and Resources, 31, 2006, pp. 297-325

Almeida, Paul, and Linda Brewster Stearns. "Political Opportunities and Local Grassroots Environmental Movements: The Case of Minamata.” In Social Problems, 45/1, Feb 1998, pp. $37-60$

Asian Development Bank. "Understanding and Responding to Climate Change in Developing Asia.” 2009, http://www.adb.org/Documents/Books/Climate-Change-Dev-Asia/ClimateChange.pdf, accessed October 2011

Central People's Government of the People's Republic of China. "Initial National Communication on Climate Change.” 2004, UNFCCC website, http://unfccc.int/resource/docs/natc/chnnc1e.pdf, accessed April 2010

Central People's Government of the People's Republic of China. "Guówùyuàn guānyú chénglì guójiā yīngduì qìhòu biànhuà jí jiénéng jiănpái gōngzuò lǐngdăo xiǎozǔ de tōngzh̄̄” 国务院关 于成立国家应对气候变化及节能减排工作领导小组的通知 [Notification by the State Council on the Instalment of a National Leading Group on Climate Change and a National Leading Group on Energy Saving and Pollution Reduction]. 2007, The Central People's Government website, http://202.123.110.3/zwgk/2007-06/18/content_652460.htm, accessed July 2010

Chinese Civil Society Coalition on Climate Change (CCSCCC). "Chinese Civil Society on Climate Change: Consensus and Strategies.” 2009, http://www.eu-china.net/web/cms/upload/pdf/ materialien/eu-china_2009_hintergrund_14.pdf, accessed June 2010

Choi, Eunhwa. "Korea's Countermeasure on Climate Change and CDM." 2004, cd4cdm website, http://www.cd4cdm.org/Asia/Manila\%20Forum/5_Choi.pdf, accessed June 2010

Fisher, Dana R. "Beyond Kyoto: the formation of a Japanese climate change regime." In Global Warming and East Asia: The Domestic and International Politics of Climate Change, edited by Paul G. Harris. New York: Routledge, 2003, pp. 187-205

Foljanty-Jost, Gesine. "NGOs in Environmental Networks in Germany and Japan: The Question of Power and Influence." In Social Science Japan Journal, 8/1, 2005, pp. 103-117

Government of Japan. “Chikyū ondanka taisaku no suishin ni kansuru hōritsu” 地球温暖化対策 の推進に関する法律 [Act on Promotion of Global Warming Countermeasures]. 1998.,Japanese Law Translation website, http://www.japaneselawtranslation.go.jp/law/detail/?id=97\&vm=04\&re=02, accessed June 2010

Government of Japan. “Enerugī no shiyō no gōrika ni kansuru hōritsu” エネルギーの使用の合 理化に関する法律 [Act on the Rational Use of Energy]. 2005a, Cabinet Secretariat website, http://www.cas.go.jp/jp/seisaku/hourei/data/rue_2.pdf, accessed June 2010

Government of Japan. "Tokutei tokushu jidōsha haishutsu gasu no kisei nado ni kansuru hōritsu" 特定特殊自動車排出ガスの規制等に関する法律 [Act on Regulation, etc. of Emissions from Non-road Special Motor Vehicles]. 2005b, Japanese Law Translation website, http://www.japaneselawtranslation.go.jp/law/detail/?id=141\&vm=04\&re=02, accessed June 2010

Government of Japan. “Japan's Fifth Communication under the United Nations Framework Convention on Climate Change." 2010, UNFCCC website, http://unfccc.int/resource/docs/natc/jpn_nc5.pdf, accessed April 2010 
Government of the Republic of Korea. "Second National Communication of the Republic of Korea under the United Nations Framework Convention on Climate Change.” 2003, ROK website, http://unfccc.int/resource/docs/natc/kornc02.pdf, accessed April 2010

Green Assembly Asia Environment. "Korean Federation for Environmental Movement." Green Assembly Asia Environment website, http://www.greenassembly.net/korea/korean-federationfor-environmental-movement/, 2010, accessed June 2010

Green Korea United. "The Counterplan of the Climate Change Report for 16 Megalopolis Government Units.” Green Korea United website, http:/green-korea.tistory.com/82, 2008, accessed June 2010

Harris, Paul G. "Introduction: the politics and foreign policy of global warming in East Asia," In Global Warming and East Asia: The Domestic and International Politics of Climate Change, edited by Paul G. Harris. New York: Routledge, 2003, pp. 3-18

Hattori, Takashi. "The Rise of Japanese Climate Change Policy: Balancing the Norms Economic Growth, Energy Efficiency, International Contribution and Environmental Protection." In The Social Construction of Climate Change: Power, Knowledge, Norms, Discourses, edited by Mary E. Pettenger. Hampshire UK: Ashgate, 2007, pp. 75-98

Heggelund, Gørild. "China's Climate Change Policy: Domestic and International Developments." In Asian Perspective, 31/2, 2007, pp. 155-191

Held, David, Eva-Maria Nag and Charles Rogers. "The Governance of Climate Change in China." LSE Global Governance Working Paper WP 01/2011, http://www2.lse.ac.uk/globalGovernance/publications/workingPapers/climateChangeInChina.p df, accessed October 2011

Héritier, Adrienne. "New Modes of Governance in Europe: Policy Making without Legislation?" In Reihe Politikwissenschaft, 81, 2002, Vienna: Institute for Advanced Studies

Hufty, Marc. "The Governance Analytical Framework." Working Paper 1, Graduate Institute of International and Development Studies, Geneva, 2009

Jeong, Hoi Seong. "Citizen Involvement in the Environmental Policy Process in Korea." In The Good Society, 11/2, 2002, pp. 46-56

Kim, Sunhyuk. The Politics of Democratization in Korea: the Role of Civil Society. Pittsburgh PA: University of Pittsburgh Press, 2000

Kjaer, Anne Mette. "Governance: an Overview of Its Usages." Paper based on a forthcoming book on governance for Polity Press 'Key Concepts' series. 2003, Roskilde Universitet website, http://www.ruc.dk/upload/application/pdf/f51d6748/Mette_Kjaer.pdf, accessed March 2010

Kohler-Koch, Beate. "The Evolution and Transformation of European Governance.” In Reihe Politikwissenschaft, 58, 1998, Vienna: Institute for Advanced Studies

Lee, Yeong Heui and Walter Bückmann. „Management der Energieeffizienz in Südkorea: Modell für Europa?" In Internationales Asienforum, 38/3-4, 2007, pp. 259-291

Lin, Jiang. "Appliance Efficiency Standards and Labeling Programs in China." In Annual Review of Energy and the Environment, 27, 2002, pp. 349-367

Mayntz, Renate. "Governance Theory als fortentwickelte Steuerungstheorie?" MPIfG Working Paper, 2004/1, http://www.mpi-fg-koeln.mpg.de/pu/workpap/wp04-1/wp04-1.html, accessed March 2010

Ministry of Environment of the ROK. "Countermeasures by MOE." 2011, Ministry of Environment South Korea website, http://eng.me.go.kr/content.do?method=moveContent\&menuCode=pol_cha_cli_cou_gov_moe , accessed November 2011 
Ministry of Government Legislation (MGL). "Rational Energy Utilization Act of the Republic of Korea." 1997, UN Economic and Social Commission for Asia and the Pacific website, http://www.unescap.org/esd/energy/publications/compend/ceccpart4chapter8.htm\#Chapter\%2 09, accessed June 2010

Ministry of Government Legislation. "Wastes Control Act of the Republic of Korea." 2007, MGL website, http://www.moleg.go.kr/FileDownload.mo?flSeq=31503, accessed June 2010

Ministry of Government Legislation. "Enforcement Decree of the Environmental Impact Assessment Act.” 2009, MGL website, http://www.moleg.go.kr/FileDownload.mo?flSeq=31508, accessed June 2010

Ministry of Government Legislation. "Enforcement Decree of the Framework Act on Low Carbon, Green Growth.” 2010a, MGL website, http://www.moleg.go.kr/FileDownload.mo?flSeq=30708, accessed June 2010

Ministry of Government Legislation. "Framework Act on Low Carbon, Green Growth." 2010b, MGL website, http://www.moleg.go.kr/FileDownload.mo?flSeq=30719, accessed June 2010

Mol, Arthur P.J. and Neil T. Carter. "China's Environmental Governance in Transition." In Environmental Governance in China, eds. Arthur P.J. Mol and Neil T. Carter. New York: Routledge, 2007, pp. 1-22

Moon, Tae Hoon. "Environmental Policy and Green Government in Korea." In Korea Journal, 44/3, Autumn 2004, pp. 220-251

National People's Congress of the People's Republic of China. "The Law on Energy Conservation of the People's Republic of China.” 1997, National People's Congress website, http://www.npc.gov.cn/englishnpc/Special/CombatingClimateChange/200908/28/content_1516263.htm, accessed June 2010

National People's Congress of the People's Republic of China. “Zhōnghuá rénmín gònghéguó sēnlín fă” 中华人民共和国森林法 [Forestation Law of the People's Republic of China]. 1998, Central People's Government website, http://www.gov.cn/banshi/200509/13/content_68753.htm, accessed June 2010

National People's Congress of the People's Republic of China. "The Renewable Energy Law of the People's Republic of China.” 2005, National People's Congress website, http://www.npc.gov.cn/englishnpc/Special/CombatingClimateChange/200908/25/content1515301.htm, accessed June 2010

National People's Congress of the People's Republic of China. "Zhōngguó yīngduì qìhòu biànhuà guójiā fāng'àn” 中国应对气候变化国家方案 [China's National Climate Change Programme]. 2007, China Climate Change Info-Net website, http://www.cchina.gov.cn/WebSite/CCChina/UpFile/File189.pdf, accessed June 2010

Nordqvist, Joakim. "Evaluation of Japan's Top Runner Programme.” 2006, AID-EE website, http://www.aid-ee.org/documents/018TopRunner-Japan.PDF, accessed June 2010

Oh, Ilyoung. "Status of the Climate Change Policies in South Korea." In Springer Proceedings in Physics, 124, 2008, pp. 485-493

Qi, Ye, Ma Li, Zhang Huanbo, and Li Huimin. "Translating a Global Issue Into Local Priority: China's Local Government Response to Climate Change." In The Journal of Environment Development, 17, December 2008, pp. 379-400

Reuters. "China says is world's top greenhouse gas emitter." November 23, 2010, http://www.reuters.com/article/2010/11/23/climate-cancun-chinaidAFTOE6AM02N20101123, accessed October 2011

Richerzhagen, Carmen and Inge Scholz. “China's Capacities for Mitigating Climate Change.” In World Development, 36/2, 2007, pp. 308-324 
Schreurs, Miranda. Environmental Policy in Japan, Germany and the United States. Cambridge: Cambridge University Press, 2002

Schreurs, Miranda. "From the Bottom Up: Local and Subnational Climate Change Politics." In The Journal of Environment Development, 17, December 2008, pp. 343-355

Schreurs, Miranda: "Top Down, Bottom Up, and Horizontal Linkages in Climate Change Policy Making: Transatlantic Perspectives.” 2009, University of Edinburgh website, www.law.ed.ac.uk/europa/files/schreurstopdownpres.ppt, accessed June 2010

Schreurs, Miranda. "Multi-level Governance and Global Climate Change in East Asia." In Asian Economy Policy Review, 2010, pp. 88-105

Schuppert, Gunnar Folke. "Governance: auf der Suche nach Konturen eines 'anerkannt uneindeutigen' Begriffs." In Governance in einer sich wandelnden Welt, edited by Gunnar Folke Schuppert. Wiesbaden: Verlag für Sozialwissenschaften, 2008, pp. 13-40.

Schwartz, Jonathan. "Environmental NGOs in China: Roles and Limits." In Pacific Affairs, 77/1, 2004, pp. 28-49

Shiel, Patrick, Nick Jeffers, and Mark Dyar. "Energy Conservation Measures in Japan.”, Paper presented at workshop on "Transatlantic Energy Efficiency, Analysis of Japan, China and India”, February 11-12, 2011, Berkeley University of California website, http://igov.berkeley.edu/trans/sites/default/files/Energy_Conservation_Measures_Japan_R4_P S_Jan_24-1.pdf, accessed October 2011

Shimizu, Yasu. “Japan's Climate Change Policy.” Power point presentation to Resources for the Future (RTF), February 12, 2004, Resources for the Future website, http://www.rff.org/rff/Events/upload/11699_1.pdf, accessed July 2010

Shin, Sangbum. "Domestic Environmental Governance and Regional Environmental Cooperation in Northeast Asia." Seoul workshop of Nautilus Institute on "Interconnections of Global Problems in East Asia: Climate Change Adaptation and its Complexity in Perspective of Civil Society Initiative”, March 16-19, 2009, Nautilus website. http://gc.nautilus.org/Nautilus/CCworkshops/seoul/workshoppapers/Domestic_Environmental_Governance_and_Cooperation_in_NEA.pdf, accessed March 2010

Stoker, Gerry. "Governance as theory: Five Propositions.” In International Social Science Journal, 50/155, 1998, pp. 17-28

Sugiyama, Noriko, and Tsuneo Takeuchi. "Local Policies for Climate Change in Japan." In The Journal of Environmental Development, 17, 2008, pp. 424-441

Treib, Oliver, Holger Bähr, and Gerda Falkner: "Modes of Governance: A Note Towards Conceptual Clarification, in: European Governance Papers." No. N-05-02, 2005, Connex Network website, http://edoc.vifapol.de/opus/volltexte/2011/2458/pdf/egp_newgov_N_05_02.pdf, accessed February 2010

Troost, Georg. "Recent Trends in Chinese Environmental Law." In Asien: Deutsche Zeitschrift für Politik, Wirtschaft und Kultur, 74, 2000, pp. 27-39

UNFCCC (United Nations Framework Convention on Climate Change). "National Communications from parties included in Annex I to the Convention - Compilation and Synthesis of Third National Communications - Compilation and synthesis report on Third National Communications - Appendum - Policies and Measures.” 2003, UNFCCC website, http://unfccc.int/resource/docs/2003/sbi/07a02.pdf, accessed March 2010

UNFCCC (United Nations Framework Convention on Climate Change). "Impacts, Vulnerabilities and Adaptation in Developing Countries." 2007, UNFCCC website, http://unfccc.int/resource/docs/publications/impacts.pdf, accessed October 2011. 
Walker, Neil. "Legal Dimension of New Modes of Governance: Background Information.” Paper presented at NEWGOV Consortium Conference, May 30-31, 2005, Florence

Williamson, Oliver E. "The institutions and governance of economic development and reform." In World Bank Economic Review, 8, 1994, pp.171-197

Zhao, Jimin. "Implementing International Environmental Treaties in Developing Countries:

China's Compliance with the Montreal Protocol." In Global Environmental Politics, 5/1, 2005, pp. 58-81 


\section{GLOSSARIES}

Japanese

Chikyū ondanka taisaku no suishin ni kansuru hōritsu

Chikyū ondanka taisaku suishin hombu

Chūō kankyō shingikai

Enerugī no shiyō no gōrika ni kansuru hōritsu

Jizoku kanō na kaihatsu no tame no kyōiku

Kābon mainasu tōkyō

Kankyō shō

Keizai sangyō shō

Kikō fōramu

Kikō nettowāku

Kyōto giteisho mokuhyō tassei keikaku

Kyōto

Minamata byō

Nagoya

Nippon keizai dantai rengōkai

Tokutei tokushu jidōsha haishutsu gasu no kisei nado ni kansuru hōritsu

Tōkyō

Toppu rannā hōshiki

WWF japan

Zenkoku chikyū ondanka bōshi katsudō suishin sentā
地球温暖化対策の推進に 関する法律

地球温暖化対策推進本部

中央環境審議会

エネルギーの使用の合理 化に関する法律

持続可能な開発のための 教育

カーボンマイナス東京

環境省

経済産業省

気候フォーラム

気候ネットワーク

京都議定書目標達成計画

京都

水俣病

名古屋

日本経済団体連合会

特定特殊自動車排出ガス の規制等に関する法律

\section{東京}

トップランナー方式

WWF ジャパン

全国地球温暖化防止活動 推進センター
Act on Promotion of Global Warming Countermeasures

Global Warming Prevention

Headquarter

Japan's Central Environmental Council

Act on the Rational Use of Energy

Education for Sustainable Development

Carbon-Minus Tokyo

Ministry of Environment

Ministry of Economy, Trade and Industry

Kiko Forum

Kiko Network

Kyōto Protocol Target Achievement Plan

Kyōto; capital of Kyōto prefec-

ture, formerly the imperial capital of Japan

Minamata disease; a neurological syndrome caused by mercury poisoning due to water pollution in Minamata

Nagoya; capital of Aichi prefecture

Keidanren; Japanese Business

Federation

Act on Regulation, etc. of Emissions from Non-road Special Motor Vehicles

Tōkyō; capital of Japan

Top Runner Programme

WWF Japan

Japan Centre on Climate Change Action 
Chinese

Běijīng 北京

Guójiā băohù chòuyăng

lǐngdăo xiăozǔ

Guójiā yīngduì qìhòu biànhuà

lǐngdăo xiăozǔ

Guójiā fāzhăn hé găigé wěi-

yuánhuì

Guójiā qìhòu biànhuà duìcè

xiétiáo wěiyuánhuì

Huánjìng băohù bù xuānchuán

jiàoyù zhōngxīn

Jiénéng jiănpái gōngzuò lǐngdăo xiǎozǔ

Kěchíxù fâzzhăn yánjiū zhôngxîn

Zhèngfǔ zhǔdăo xiàde shètuán zǔzhī

Zhōngguó biānzhǔnhuà yánjiūsuǒ

Zhōngguó gōngmín shèhuì

yîngduì qìhòu biànhuà lìchăng

Zhōngguó guójiā huánjìng

băohù zǒngjú

Zhōngguó huánjìng yǔ fāzhăn

yīng căiqǔ de shí dà duìcè

Zhōngguó shèhuì kēxuéyuàn

Zhōngguó yīngduì qìhòu biànhuà guójiā fāng'àn

Zhōnghuá huánjìng băohù

jījīnhuì

Zhōnghuá rénmín gònghéguó jiéyuē néngyuán fã

Zhōnghuá rénmín gònghéguó

kězàishēng néngyuán fã

Zhōnghuá rénmín gònghéguó sēnlín fã

\section{国家保护臭氧领导小组 \\ 国家应对气候变化领导小 \\ 组 \\ 国家发展和改革委员会}

国家气候变化对策协调委

员会

环境保护部宣传教育中心

节能减排工作领导小组

可持续发展研究中心

政府主导下的社团组织

中国标准化研究所

中国公民社会应对气候变

化立场

中国国家环境保护总局

中国环境与发展应采取的

十大对策

中国社会科学院

中国应对气候变化国家方 案

中华环境保护基金会

中华人民共和国节约能源

法

中华人民共和国可再生能 源法

中华人民共和国森林法
Běijīng; capital of the People's

Republic of China

National Leading Group for

Ozone Layer Protection

National Leading Group on

Climate Change

National Development and

Reform Commission

National Coordination Committee on Climate Change

Centre for Environmental Education and Communications

National Leading Group on

Energy Saving and Pollution

Reduction

Research Centre for Sustainable

Development

Government-operated Non-

Governmental Organisations

China National Institute for

Standardization

Chinese Civil Society on Cli-

mate Change

State Environmental Protection

Administration

Ten-point Policy for Environ-

ment and Development

Chinese Academy of Social

Science

China's National Climate

Change Programme

China Environmental Protection

Foundation

Law on Energy Conservation of the People's Republic of China Renewable Energy Law of the People's Republic of China Forestation Law of the People's Republic of China 


\section{Korean}

Chŏt'anso noksaeksŏngjang kibonbŏp

Chungang hwan'gyŏng pojŏn hyŏbŭihoe

Enŏji iyong hamni hwabŏp

Enǒjisang susang

Hwan'gyŏngbu

Hwan'gyŏng undong yŏnhap

Hwan'gyŏng

yŏnghyangp'yŏng kabŏp

Kohyoyul enŏji sayong injŭng chedo

$\begin{array}{ll}\text { Kungmu chojŏngsil } & \text { 국무조정실 } \\ \begin{array}{l}\text { Kungnip hwan'gyŏng } \\ \text { kwahagwŏn }\end{array} & \text { 국립환경과학원 } \\ \text { Kungnip kisang yŏn'guso } & \text { 국립기상연구소 } \\ \text { Kŭrin pilding injŭng chedo } & \text { 그린빌딩 인증제도 } \\ \text { Noksaek sŏngjang wiwŏnhoe } & \text { 녹색성장 위원회 } \\ \begin{array}{l}\text { P’yegi mulbŏp } \\ \text { Sanŏp chawŏnbu }\end{array} & \text { 폐기물법 } \\ \text { Seoul } & \text { 산업자원부 } \\ \begin{array}{l}\text { Taegi chŏllyŏk chŏgam } \\ \text { p'ŭrogŭraem }\end{array} & \text { 서울 } \\ \text { Taehan sanggong hoeŭiso } & \text { 대기전력 저감 프로그램 } \\ \text { Ǔije } 21 & \text { 대한상공회의소 } \\ \text { Ulsan } & \text { 의제 } 21 \\ & \text { 울산 }\end{array}$

Yuen kihu pyŏnhwa hyŏbyak changgwan hoeŭi
저탄소 녹색성장 기본법

중앙 환경보전 협의회

에너지이용 합리화법

에너지상 수상

환경부

환경운동연합

환경영향평가법

고효율 에너지 사용

인증제도

국무조정실

국립환경과학원

국립기상연구소

그린빌딩 인증제도

폐기물법

서울

대기전력 저감 프로그램

대한상공회의소

유엔기후변화협약 장관회의
Low Carbon Green Growth

Strategy

Central Environmental

Conservation Council

Rational Energy Utilisation Act

Energy Winner Prize

Ministry of Environment

Korean Foundation for

Environmental Movement

Environmental Impact

Assessment Act

High-Efficiency Energy Using

Appliance Certification

Programme

Office of Government Policy

Coordination

National Institute of

Environmental Research

National Institute of

Meteorological Research

Green Building Certification

Programme

Presidential Committee on Green

Growth

Waste Law

Ministry of Industry and

Resources

Sŏul; capital of South Korea

E-standby Programme

Korean Chamber of Commerce and Industry

Agenda 21

South Korea's seventh largest metropolis, located in the southeast of the country Inter-Ministerial Committee on UNFCCC 